\title{
Is There a Positive Synergistic Effect of Biochar and Compost Soil Amendments on Plant Growth and Physiological Performance?
}

\author{
M. Lukas Seehausen, Nigel V. Gale *, Stefana Dranga, Virginia Hudson, Norman Liu, \\ Jane Michener, Emma Thurston, Charlene Williams, Sandy M. Smith and Sean C. Thomas \\ Faculty of Forestry, University of Toronto, 33 Willcocks Street, Toronto, ON M5S 3B3, Canada; \\ ml.seehausen@mail.utoronto.ca (M.L.S.); stefana.dranga@mail.utoronto.ca (S.D.); vehudson8@gmail.com (V.H.); \\ changnorman.liu@mail.utoronto.ca (N.L.); jane.michener@mail.utoronto.ca (J.M.); \\ emma.thurston@mail.utoronto.ca (E.T.); charleneawi@gmail.com (C.W.); s.smith.a@utoronto.ca (S.M.S.); \\ sc.thomas@utoronto.ca (S.C.T.) \\ * Correspondence: nigel.gale@mail.utoronto.ca; Tel.: +1-647-833-4352
}

Academic Editor: Lukas Van Zwieten

Received: 31 December 2016; Accepted: 7 February 2017; Published: 11 February 2017

\begin{abstract}
The combination of biochar (BC) with compost has been suggested to be a promising strategy to promote plant growth and performance, but although "synergistic" effects have been stated to occur, full-factorial experiments are few, and explicit tests for synergism are lacking. We tested the hypothesis that a combination of BC and spent mushroom substrate (SMS) has a positive synergistic effect on plant growth and physiological performance in a nutrient-limited growing media. A greenhouse experiment with a full factorial design was conducted using mixed-wood BC $\left(3.0 \mathrm{~kg} \cdot \mathrm{m}^{-2}\right)$ and SMS $\left(1.5 \mathrm{~kg} \cdot \mathrm{m}^{-2}\right)$ (the combination was not co-composted) as organic soil amendments for the annual Abutilon theophrasti and the perennial Salix purpurea. Several measurements related to plant growth and physiological performance were taken throughout the experiment. Contrary to the hypothesis, we found that the combination of BC + SMS had neutral or antagonistic interactive effects on many plant growth traits. Antagonistic effects were found on maximum leaf area, above- and belowground biomass, reproductive allocation, maximum plant height, chlorophyll fluorescence, and stomatal conductance of $A$. theophrasti. The effect on S. purpurea was mostly neutral. We conclude that the generalization that $\mathrm{BC}$ and compost have synergistic effects on plant performance is not supported.
\end{abstract}

Keywords: biochar; compost; spent mushroom substrate; soil amendments; synergistic effects; Abutilon theophrasti; Salix purpurea

\section{Introduction}

Charcoal derived from wildfire plays an integral role in the re-vegetation and function of ecosystems following disturbances. Soil pyrogenic carbon provides numerous services to plants, sorbing many growth-inhibitory compounds (e.g., phenolics, salts, metals) [1,2], basifying acidified soils concomitant with improving nutrient retention and exchange [3], delivering a pulse of water-soluble elements available for plants and soil fauna [4,5], and improving soil water holding capacity [6]. When charcoal is applied as a soil amendment, the term "biochar" (BC) is used [7]. In managed systems, $\mathrm{BC}$ has received much attention for its potential to improve soil fertility and to mitigate climate change by carbon sequestration (e.g., [8-10]). In recent meta-analyses, Jeffrey et al. [11] and Biederman and Harpole [12] show that BC increases crop yields by an average of $10 \%$ and $30 \%$, respectively, while Thomas and Gale [13] report a mean biomass growth response of $41 \%$ for woody plants. 
Similar to natural charcoals, BCs contain high specific surface area, cation exchange capacities and microporosity, properties that have improved plant growth and function across systems. These properties greatly depend on the feedstock (e.g., waste products from forestry and agriculture such as woodchips, sawdust, corn-stover, manure, etc.), the pyrolysis process (e.g., fast, slow, and gasification), and the temperature during pyrolysis [3,14]. BCs derived from woody feedstock demonstrate particularly important ameliorative properties that include high ability to sorb soil contaminants [15], retain nutrients and water [16-18], increase soil $\mathrm{pH}$, and provide pulses of nutrients that are potentially limiting in certain systems (e.g., phosphorus in Pluchon et al. [19]).

Compost is another soil amendment heralded for multiple benefits as an organic fertilizer that results in well-documented increases in plant growth $[20,21]$. Spent mushroom substrate (SMS), also called mushroom compost, is a by-product of the mushroom industry that is commonly used as a soil amendment, and has shown particularly strong positive effects on plant growth and soil function [22]. Like BC, mushroom compost generally limes soils and increases the availability and uptake of nutrients-especially N, P, and K [23,24]. However, negative growth responses have occasionally been reported possibly due to high salinity or metal concentration in compost [25]. Mushroom compost has improved fruit yield in several agricultural crops in the relative short term (one growing season) at high dosages $\left(4.0-8.0 \mathrm{~kg} \cdot \mathrm{m}^{-2}\right)$ [24,26]; however, the effects of mushroom compost on the growth and performance of woody plants/crops have only been minimally investigated [27].

In the broader scientific literature, "synergistic" effects are essentially always defined as a deviation from an additive model, such as that described by analysis of variance; this definition is likewise well established in the plant nutrition literature ([28], p. 39). It has been repeatedly suggested that the combination of $\mathrm{BC}$ with compost may be a promising strategy to promote plant growth and performance, having positive synergistic effects on soil properties and plant growth responses (e.g., [29-31]). Synergistic effects of a BC-compost blend on plant growth and performance are thought to be mediated by sorption of nutrients by the porous BC matrix [29], stimulation of microbial colonization [32], degradation of possible noxious pyrogenic substances [33], improvement of the BC surface reactivity through accelerated oxidative ageing [34,35] and dissolved organic carbon sorption [36]. The hypothesized synergy is likely to be particularly effective in offsetting potentially toxic effects of high metal and salt concentrations in SMS since BCs have demonstrated the ability to mitigate salt stress [15] and metal bioavailability [1]. Indeed, recent work by Beesley et al. [37] shows promise for BC-compost applications to soils contaminated by metals and arsenic. Multiple studies have been conducted on the effect of $\mathrm{BC}$ on soil properties and plant growth together with, or in comparison to compost and/or other fertilizers both in the field [31,38-44] and in greenhouses [45-49]. Although many studies report positive effects of a BC-compost mix on soil properties and plant growth, there is a lack of explicit tests for synergistic effects in the literature: we are aware of only a few prior experiments that have utilized a factorial experimental design [43,45,49].

In the present study, we tested the effect of a mixed-wood BC, SMS, and a combination of both (not co-composted prior to application), on plant growth and physiological performance of two plant species: the annual Abutilon theophrasti Medik (Malvaceae) and the perennial Salix purpurea L. (Salicaceae). We tested the hypothesis that a combination of BC and SMS has a positive synergistic effect on plant growth and physiological performance in nutrient-limited media. We expected that responses would be particularly dramatic in Abutilon theophrasti, an annual plant known for opportunistic nutrient uptake [50]. We expected that the response of the woody perennial S. purpurea would be relatively less pronounced, but of broad interest due to being a common bioenergy crop species [51].

\section{Materials and Methods}

\subsection{Growth Conditions and Experimental Design}

The experiment was conducted in a University of Toronto glasshouse situated at the St. George Campus, in Ontario, Canada. Mean temperature in the glasshouse averaged $26^{\circ} \mathrm{C}$ during the day and $18{ }^{\circ} \mathrm{C}$ during night, with $40 \%$ mean relative humidity and a $16: 8 \mathrm{~h}$ light-dark period. 
A completely randomized factorial design was used with two treatment factors, BC and SMS additions, and two plant species, Abutilon theophrasti and Salix purpurea (var. 9882-41). Abutilon theophrasti seeds originated from agricultural weed populations in southern Illinois and were purchased through V\&S Seed Supply (City, Illinois, USA). Salix purpurea cuttings originated from the Faculty of Environmental Science and Forestry at the State University of New York, NY, USA, and were obtained from the University of Guelph's long-term agroforestry trials in Guelph, Ontario, Canada, in January 2015. The BC used in the experiment was produced through slow pyrolysis of mixed wood from shipping and construction materials produced at a pyrolysis temperature of $700{ }^{\circ} \mathrm{C}$ for $30 \mathrm{~min}$. The biochar used here has been extensively characterized elsewhere (see "old Burt's" biochar in [52]), was shown not to have elevated levels of metals or organic compounds, and additionally passed germination assays and earthworm avoidance tests in accordance with the International Biochar Initiative's procedures. Additionally, the same biochar has been utilized in two prior studies showing its potential to remove soil contaminants [53,54]. Biochar was heat-treated at $100{ }^{\circ} \mathrm{C}$ for $24 \mathrm{~h}$ prior to use in the experiment to alleviate potentially phytotoxic compounds leachable from BC [55]. Commercially available SMS (Premier Tech, Premier ${ }^{\circledR}$, RiviÙre-du-Loup, Québec, Canada) was used. Chemical properties of the BC and SMS used in the experiment are listed in Table 1.

Table 1. Chemical properties of biochar and compost. Compost analysis was conducted at the Agriculture and Food Laboratory, University of Guelph, Guelph, ON. Biochar analyses were conducted at the Analytic Services Unit, Queen's University, Kingston, ON and derived from Denyes et al. [52]. Test procedures and units are reported in parenthesis. BC: biochar; SMS: spent mushroom substrate.

\begin{tabular}{ccc}
\hline Attribute & Value for SMS & Value for BC \\
\hline Ammonium-N $\left(\mathrm{KCl}-\mathrm{NH}_{4}, \mathrm{mg} \cdot \mathrm{kg}^{-1}\right)$ & 10 & 2 \\
Nitrate-N $\left(\mathrm{KCl}-\mathrm{NH}_{4}, \mathrm{mg} \cdot \mathrm{kg}^{-1}\right)$ & 388 & 3.0 \\
Phosphorus $\left(\mathrm{NaHCO}_{3}, \mathrm{mg} \cdot \mathrm{L}^{-1}\right)$ & 120 & 31 \\
Magnesium $\left(\mathrm{NH}_{4} \mathrm{C}_{2} \mathrm{H}_{3} \mathrm{O}_{2}, \mathrm{mg} \cdot \mathrm{L}^{-1}\right)$ & 820 & 848 \\
Potassium $\left(\mathrm{NH}_{4} \mathrm{C}_{2} \mathrm{H}_{3} \mathrm{O}_{2}, \mathrm{mg} \cdot \mathrm{L}^{-1}\right)$ & 2000 & 2150 \\
Manganese $\left(\mathrm{NH}_{4} \mathrm{C}_{2} \mathrm{H}_{3} \mathrm{O}_{2}, \mathrm{mg} \cdot \mathrm{L}^{-1}\right)$ & 4.3 & 752 \\
Zinc $\left(\mathrm{NH}_{4} \mathrm{C}_{2} \mathrm{H}_{3} \mathrm{O}_{2}, \mathrm{mg} \cdot \mathrm{L}^{-1}\right)$ & 8.2 & 5.6 \\
$\mathrm{pH}\left(\mathrm{CaCl}_{2}\right)$ & 6.4 & 10.6 \\
\hline
\end{tabular}

A non-fertilized growth medium consisting of peat moss (70\%), perlite $(20 \%)$ and sand $(10 \%)$ was used, in which the BC $\left(1.5 \mathrm{~kg} \cdot \mathrm{m}^{-2}\right)$, SMS $\left(3.0 \mathrm{~kg} \cdot \mathrm{m}^{-2}\right)$, or a combined mixture of BC and SMS $\left(1.5 \mathrm{~kg} \cdot \mathrm{m}^{-2}\right.$ and $3.0 \mathrm{~kg} \cdot \mathrm{m}^{-2}$, respectively) soil amendments were completely mixed, forming the treatments of the experiment. The control treatment did not contain BC or SMS. There were 20 replicates ( 1 plant/pot) planted per plant species and treatment, with a total of 160 pots ( 2 species $\times 4$ treatments $\times 20$ replicates). The water content of the SMS was $41.10 \% \pm 0.17 \%$ ( $n=10$ samples of $10 \mathrm{~g}$ each, dried for $48 \mathrm{~h}$ at $60{ }^{\circ} \mathrm{C}$ ), therefore the dosage on dry mass basis was $\sim 1.76 \mathrm{~kg} \cdot \mathrm{m}^{-2}$. Dosages for BC and SMS were calculated relative to pot soil surface area ( $200 \mathrm{~cm}^{2} / 4$-L pot; $30 \mathrm{~g} \mathrm{BC}$ and/or $60 \mathrm{~g} \mathrm{SMS/pot)}$ and are in the range of dosages used in previous studies that improved plant growth (e.g., $[24,26,56])$. Abutilon theophrasti seeds were germinated in a non-soil growing mix seven days prior to planting. Cuttings of $S$. purpurea were shortened to $30 \mathrm{~cm}$ in length and were inserted into pots to a depth of $5-7 \mathrm{~cm}$. Planting took place on 21 January 2015 and plants were grown for 91 days until 22 April 2015. The placement of the pots was completely randomized on one glasshouse table.

\subsection{Plant Growth and Physiological Performance}

To calculate leaf area of both plant species, the length of every leaf on each individual plant was measured to the nearest $0.5 \mathrm{~cm}$ on a weekly basis from 2 February 2015 onwards (12 days after planting). A species-specific allometric equation was applied to estimate area/leaf, and sum these 
estimates across all leaves. For $A$. theophrasti, the equation described in Thomas et al. [57] was used: $A$ $=0.6519 \times L^{1.9523}$, where $A$ is leaf area in $\mathrm{cm}^{2}$ and $L$ is leaf length in $\mathrm{cm}$. An allometric equation was developed for S. purpurea following the methods described in Thomas et al. [57]: $A=0.1882 \times L^{2}$.

To investigate physiological plant responses to the treatments, leaf-level gas-exchange parameters were measured on 18 March 2015 (44 days after planting-approximately halfway through the experiment) between 09:00 am-02:00 pm local time. Light-saturated photosynthetic rate and stomatal conductance were measured using an LI-6400xt Portable Photosynthesis System (Li-Cor, Lincoln, NE, USA). Triplicate measurements were taken on the most recently developed fully-expanded leaf of each plant using a $6-\mathrm{cm}^{2}$ leaf cuvette. The system flow rate was set to $400 \mathrm{mmol} / \mathrm{s}$, and $\mathrm{CO}_{2}$ concentration of the sample set to $400 \mathrm{ppm}$. Relative humidity in the chamber was maintained at approximately $50 \%$. A red-blue light source (Licor 6000-02B) was used to maintain a photosynthetic photon flux density of $1000 \mu \mathrm{mol} \cdot \mathrm{m}^{-2} \cdot \mathrm{s}^{-1}$ during measurements. Gas flux rates were monitored during measurements to ensure steady-state values prior to recording data.

Dark-adapted photosynthetic yield (the ratio of variable to maximal fluorescence: $\mathrm{Fv} / \mathrm{Fm}$ ) was measured on 16 March 2015 (52 days after planting) between 09:00 am-02:00 pm local time with a Walz MINI-PAM Fluorometer (Heinz Walz, Effeltrich, Germany), using the saturation pulse method [58]. Plants were dark acclimated prior to measurements for several hours at a light level of $<1 \mu \mathrm{mol} \cdot \mathrm{m}^{-2} \cdot \mathrm{s}^{-1}$ of incident photosynthetically active radiation. Measurements were taken on three recently fully-expanded leaves of $A$. theophrasti and three random leaves of about the same age and size for S. purpurea.

Reproductive performance of $A$. theophrasti was measured by determining the proportion of flowering plants (number of flowering plants/total number of plants) at seven dates between 19 March and 15 April 2015 (days 57-84 after planting) and the proportion of plants with fruits at six dates between 23 March and 15 April 2015 (days 61-84 after planting).

At harvest, plant height was measured for A. theophrasti and total branch length for S. purpurea. For the latter measurement, all branches were measured to the closest $0.5 \mathrm{~cm}$ and measurements were summed for all individual plants. Stem diameter increase at soil surface of S. purpurea was calculated by subtracting the initial stem diameter measured at the onset of the experiment from the stem diameter at harvest. All plants were then cut at soil surface and roots were thoroughly washed with water to free them from the growth medium. Biomass was dried for $48 \mathrm{~h}$ at $60{ }^{\circ} \mathrm{C}$, after which above- and belowground biomass was measured and the root mass fraction (belowground biomass/aboveground biomass) calculated. For A. theophrasti, reproductive allocation of each plant was also calculated as mass of reproductive parts (flowers and fruits)/aboveground biomass.

\subsection{Statistical Analysis}

Effects of BC, SMS, and their interaction on plant growth and physiological metrics were tested by submitting data to analysis of variance (ANOVA), using the $\mathrm{glm}$ procedure (generalized linear model) in the statistical software R [59]. A significant positive BC $\times$ SMS interaction term was considered evidence for synergism, and a significant negative $B C \times S M S$ interaction term evidence for antagonism.

To test the effect of treatment (BC, SMS, BC + SMS) on leaf area over the growing period, repeated measures ANOVAs were employed using time, a parabolic term of time (time $\left.{ }^{2}\right)$, treatment, the interaction of time and treatment, and the interaction of the parabolic term of time and treatment as explanatory variables. The dates of leaf area sampling were used in the random statement of the model and a variance components covariance structure was specified (PROC MIXED; SAS Inc., Cary, NC, USA, 2015 [60]). Leaf area data were log transformed to meet the assumptions of normality and homoscedasticity of residuals.

Treatment effects on photosynthetic rate, stomatal conductance, chlorophyll fluorescence, above- and belowground biomass, plant height, root mass fraction, reproductive allocation, branch length, and stem diameter gain were analyzed using a one-way ANOVA with treatment as an explanatory variable respectively for each dependent variable (PROC GLM; SAS Inc. 2015). A $\log$ transformation was used for stomatal conductance of S. purpurea, as well as root mass fraction 
and belowground biomass of $A$. theophrasti to meet the assumptions of normality and homoscedasticity of residuals. Because these assumptions could not be met for residuals with a transformation of A. theophrasti chlorophyll fluorescence data, non-parametric Wilcoxon Scores (rank sums) followed by a Kruskal-Wallis Test were used (PROC NPAR1WAY; SAS Inc. 2015).

Repeated measures logistic regression with a binomial distribution was used to analyze the effect of soil treatments on the proportion of $A$. theophrasti with flowers and fruits over time separately (PROC GLIMMIX; SAS Inc. 2015). Time, treatment, and the interaction of time and treatment were taken as explanatory variables in both analyses and a second-order polynomial term of time and the interaction of this term with treatment were added as explanatory variables to analyze the proportion of flowering plants.

In all cases, model assumptions, such as normality and homoscedasticity of residuals, were met and Tukey's range test was used for comparisons of means, unless stated otherwise.

\section{Results}

\subsection{Effects of Biochar and Compost on Plant Growth and Performance}

Relative to the control treatment, the application of $\mathrm{BC}$ alone had a significant positive effect on belowground biomass, maximum plant height and $\mathrm{Fv} / \mathrm{Fm}$ of $A$. theophrasti, and on the proportion of root biomass of $S$. purpurea, but a significant negative effect on stomatal conductance of $S$. purpurea (Table 2). The SMS main effect was positive and significant for belowground biomass, reproductive allocation, maximum plant height, $\mathrm{Fv} / \mathrm{Fm}$, and stomatal conductance of A. theophrasti. In S. purpurea, the SMS main effect was negative for maximum leaf area, above- and belowground biomass, total branch length, and $\mathrm{Fv} / \mathrm{Fm}$ (Table 2). The $\mathrm{BC} \times \mathrm{SMS}$ interaction term was significant and negative for maximum leaf area, above- and belowground biomass, reproductive allocation, maximum plant height, $\mathrm{Fv} / \mathrm{Fm}$, and stomatal conductance of $A$. theophrasti. The only cases of significant positive BC $\times$ SMS interactions were for the root mass fraction of $A$. theophrasti and aboveground biomass of S. purpurea (Table 2). In the latter case, the main effects of BC and SMS were negative (significantly so for the latter), thus the significant positive interaction terms indicate that addition of one soil amendment mitigates the negative effects of the other.

Table 2. Two-way analysis of variance (ANOVA) table of $F$ - and $p$-values for the effects ( $+=$ positive; $-=$ negative) of biochar $(\mathrm{BC})$, spent mushroom substrate $(\mathrm{SMS})$, and their interaction $(\mathrm{BC} \times \mathrm{SMS})$ on various measurements of plant growth and physiological performance relative to control conditions without soil amendments for (a) Abutilon theophrasti and (b) Salix purpurea. Degrees of freedom (df) of the error term $=d f_{\text {error }}, d f$ of each effect $=1$.

\begin{tabular}{|c|c|c|c|c|c|c|c|c|c|c|}
\hline \multirow{2}{*}{ Measurement } & \multicolumn{3}{|c|}{ BC } & \multicolumn{3}{|c|}{ SMS } & \multicolumn{3}{|c|}{ BC $\times$ SMS } & \multirow{2}{*}{$d f_{\text {error }}$} \\
\hline & $F$ & $p$ & Effect & $F$ & $p$ & Effect & $F$ & $p$ & Effect & \\
\hline \multicolumn{11}{|l|}{ (a) Abutilon theophrasti } \\
\hline Maximum leaf area & 0.042 & 0.8380 & & 0.113 & 0.7370 & & 23.522 & $<0.0001$ & - & 76 \\
\hline Aboveground biomass & 3.869 & 0.0528 & & 3.451 & 0.0671 & & 31.657 & $<0.0001$ & - & 76 \\
\hline Belowground biomass & 5.758 & 0.0189 & + & 8.543 & 0.0046 & + & 12.671 & 0.0006 & - & 76 \\
\hline Root mass fraction & 0.193 & 0.6614 & & 0.095 & 0.7593 & & 6.701 & 0.0115 & + & 76 \\
\hline Reproductive allocation & 0.238 & 0.6273 & & 17.682 & 0.0001 & + & 13.077 & 0.0005 & - & 76 \\
\hline Maximum plant height & 6.037 & 0.0163 & + & 6.745 & 0.0113 & + & 35.076 & $<0.0001$ & - & 76 \\
\hline Chlorophyll fluorescence & 8.998 & 0.0037 & + & 11.351 & 0.0012 & + & 7.981 & 0.0060 & - & 76 \\
\hline Photosynthetic rate & 1.491 & 0.2300 & & 0.348 & 0.5590 & & 1.996 & 0.1660 & & 36 \\
\hline Stomatal conductance & 1.743 & 0.1951 & & 19.533 & 0.0001 & + & 10.455 & 0.0026 & - & 36 \\
\hline \multicolumn{11}{|l|}{ (b) Salix purpurea } \\
\hline Maximum leaf area & 2.074 & 0.1542 & & 8.479 & 0.0048 & - & 0.080 & 0.7777 & & 70 \\
\hline Aboveground biomass & 4.661 & 0.0351 & - & 15.669 & 0.0002 & - & 6.097 & 0.0166 & + & 57 \\
\hline Belowground biomass & 0.052 & 0.8203 & & 8.060 & 0.0064 & - & 0.810 & 0.3723 & & 53 \\
\hline Root mass fraction & 10.325 & 0.0022 & + & 1.694 & 0.1988 & & 3.633 & 0.0621 & & 53 \\
\hline Total branch length & 3.038 & 0.0869 & & 15.764 & 0.0002 & - & 0.816 & 0.3704 & & 55 \\
\hline Stem diameter gain & 1.672 & 0.2010 & & 2.169 & 0.1470 & & 2.450 & 0.1230 & & 55 \\
\hline Chlorophyll fluorescence & 0.023 & 0.8799 & & 9.822 & 0.0026 & - & 0.158 & 0.6926 & & 66 \\
\hline Photosynthetic rate & 0.045 & 0.8330 & & 1.326 & 0.2570 & & 2.565 & 0.1180 & & 36 \\
\hline Stomatal conductance & 4.208 & 0.0476 & + & 0.998 & 0.3245 & & 1.353 & 0.2525 & & 36 \\
\hline
\end{tabular}




\subsection{Leaf Area Growth}

Mean total leaf area of $A$. theophrasti was significantly influenced by all explanatory variables, including the interaction time ${ }^{2} \times$ treatment (Table 3). Total leaf area of plants treated with $\mathrm{BC}$ and SMS, respectively, reached a maximum of about $200 \mathrm{~cm}^{2}$ around 40 days into the experiment.

However, leaf area of plants treated with BC + SMS or growing under control conditions increased more slowly than plants in the two other treatments and reached a maximum of only about $130 \mathrm{~cm}^{2}$ (Figure 1a). A comparison of means revealed that only leaf area of plants in the BC + SMS treatment was significantly reduced compared to plants with BC or SMS treatments; however, none of the soil amendment treatments were significantly different from the control.

The interaction time $e^{2} \times$ treatment was not significant in the case of leaf area of $S$. purpurea and was therefore excluded from the analysis. Leaf area increase of $S$. purpurea over time was significantly described by time and time ${ }^{2}$ (Table 3). However, the significant linear interaction time $\times$ treatment showed that while initially the increasing trend in leaf area was similar in all treatments, the highest average leaf area per plant (of about $280 \mathrm{~cm}^{2}$ ) was reached by plants in control treatments (Figure 1b). The significant treatment effect followed by comparisons of means showed that overall, only the leaf area of plants in the $\mathrm{BC}+\mathrm{SMS}$ treatment was significantly lower than that of plants growing under control conditions.

Table 3. Results of statistical analyses testing the effect of different explanatory variables on leaf area of Abutilon theophrasti and Salix purpurea (repeated measures analysis of variance), and on the proportion of $A$. theophrasti flowers (logistic regression).

\begin{tabular}{cccccccccc}
\hline \multirow{2}{*}{ Explanatory Variable } & \multicolumn{3}{c}{ A. theophrasti Leaf Area } & \multicolumn{3}{c}{ S. purpurea Leaf Area } & \multicolumn{3}{c}{ A. theophrasti Flowers } \\
\cline { 2 - 9 } & $\boldsymbol{F}$ & $\boldsymbol{d f}$ & $\boldsymbol{p}$ & $\boldsymbol{F}$ & $\boldsymbol{d f}$ & $\boldsymbol{p}$ & $\boldsymbol{F}$ & $d f$ \\
\hline Time & 1541.8 & 1,76 & $<0.0001$ & 612.0 & 1,71 & $<0.0001$ & 20.4 & 1,10 & 0.0011 \\
Time & 1482.9 & 1,609 & $<0.0001$ & 1034.6 & 1,380 & $<0.0001$ & 21.2 & 1,10 & 0.0010 \\
Treatment & 7.1 & 3,609 & 0.0001 & 4.9 & 3,380 & 0.0024 & 4.3 & 3,10 & 0.354 \\
Time $\times$ treatment & 14.2 & 3,609 & $<0.0001$ & 4.0 & 3,380 & 0.0080 & 4.1 & 3,10 & 0.0395 \\
Time $^{2} \times$ treatment & 21.1 & 3,609 & $<0.0001$ & & removed & & 3.9 & 3,10 \\
\hline
\end{tabular}

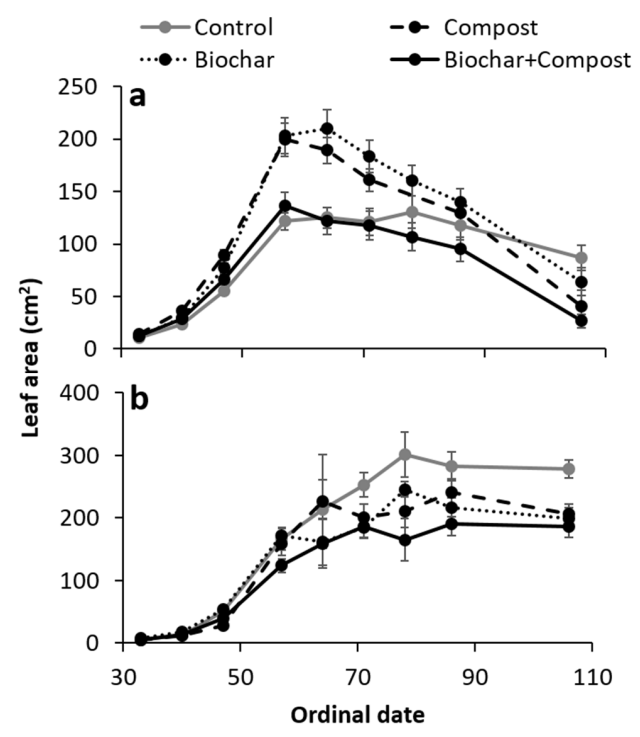

Figure 1. Mean ( \pm standard error) leaf area of (a) Abutilon theophrasti and (b) Salix purpurea over time (ordinal date) during the greenhouse experiment.

\subsection{Physiological Performance}

Photosynthetic rate, stomatal conductance, and chlorophyll fluorescence of $A$. theophrasti were significantly influenced by the treatments (Table 4a). All three physiological traits showed significant increases for $A$. theophrasti in all soil amendment treatments when compared to plants in control 
conditions. Compared to the control, photosynthetic rate was increased $\sim 3$-fold in all treatments, stomatal conductance increased $\sim 2.5$-fold by SMS and $\sim 1.7$-fold by BC and BC + SMS, and an $\sim 5 \%$ increase in Fv/Fm in all treatments was observed. Additionally, SMS significantly increased stomatal conductance of $A$. theophrasti by about $70 \%$ when compared to BC or BC + SMS (Figure 2a-c). For S. purpurea, $\mathrm{Fv} / \mathrm{Fm}$ and stomatal conductance, but not photosynthetic rate were significantly influenced by the treatments (Table 4a). However, Tukey's range test only revealed a significantly reduced stomatal conductance in the $\mathrm{BC}+\mathrm{SMS}$ treatment when compared to controls, but no significant treatment effects on Fv/Fm (Figure 2d-f).

Table 4. Results of the analysis of variance (ANOVA) testing the influence of treatments and control on measurements taken on Abutilon theophrasti and Salix purpurea.

\begin{tabular}{llccccc}
\hline \multirow{2}{*}{ Measurement } & \multicolumn{2}{c}{ Abutilon theophrasti } & \multicolumn{3}{c}{ Salix purpurea } \\
\cline { 2 - 7 } & \multicolumn{1}{c}{$\boldsymbol{F}$} & $d f$ & $\boldsymbol{p}$ & $\boldsymbol{F}$ & $d f$ & $\boldsymbol{p}$ \\
\hline (a) Physiological response & & & & & & \\
\hline Photosynthetic rate & 25.4 & 3 & $<0.0001$ & 1.3 & 3 & 0.2855 \\
Stomatal conductance & 15.1 & 3 & $<0.0001$ & 3.6 & 3 & 0.0224 \\
Chlorophyll fluorescence & 21.9 & 3 & $<0.0001$ & 3.3 & 3 & 0.0246 \\
\hline (b) Measurements taken at harvest & & & & & & \\
\hline Aboveground biomass & 13.0 & 3 & $<0.0001$ & 8.8 & 3 & $<0.0001$ \\
Belowground biomass & 12.5 & 3 & $<0.0001$ & 3.0 & 3 & 0.0398 \\
Root mass fraction & 2.9 & 3 & 0.0393 & 5.2 & 3 & 0.0031 \\
\hline
\end{tabular}

* values based on non-parametric Wilcoxon Scores (Rank Sums) followed by a Kruskal-Wallis Test.

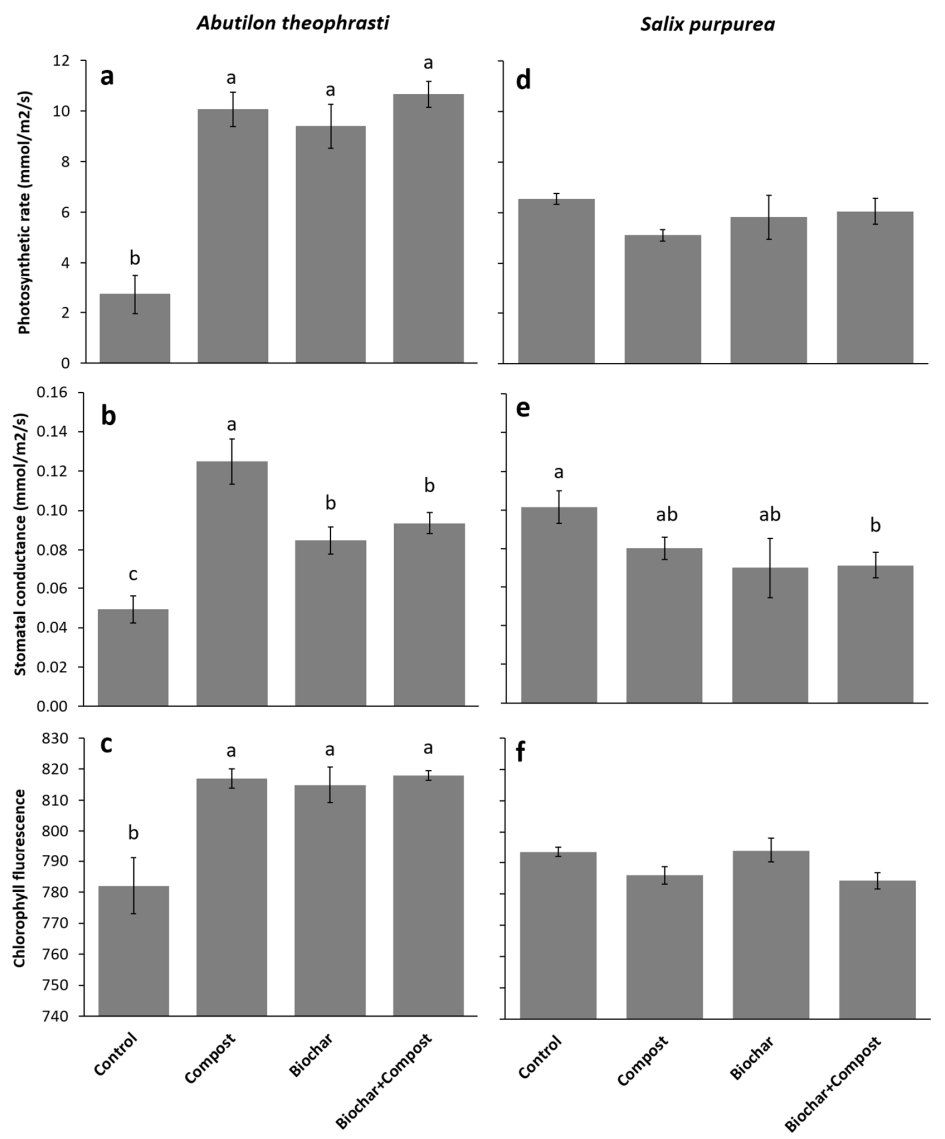

Figure 2. Mean ( \pm standard error) light-saturated photosynthetic rate, stomatal conductance under light-saturated conditions, and ratio of variable to maximal chlorophyll fluorescence for Abutilon theophrasti $(\mathbf{a}-\mathbf{c})$ and Salix purpurea $(\mathbf{d}-\mathbf{f})$ at different soil treatments. Bars in each panel with the same lower case letters do not differ significantly at $p<0.05$ according to Tukey's range test. 


\subsection{Reproductive Performance of $A$. theophrasti}

The development of $A$. theophrasti flowers over time was best described by the interaction time $^{2} \times$ treatment (Table 3; Figure 3a). Flowers were first produced by plants in BC treatments, followed by plants with BC + SMS. Flowers were produced somewhat later in SMS treatments. Plants in control conditions flowered $\sim 7$ days later than those in soil amendment treatments (Figure 3a). However, while the maximum proportion of flowers was around 40\% for BC, BC + SMS, and controls, the highest proportion of flowering plants was reached in the SMS treatment (80\%) (Figure 3a).

Fruit formation by $A$. theophrasti significantly increased over time $\left(F_{1,14}=34.03 ; p<0.0001\right)$ and was significantly influenced by treatments $\left(F_{3,14}=15.70 ; p<0.0001\right)$, but there was no time $\times$ treatment interaction. Similar to flower production, the first fruits were formed by $A$. theophrasti in BC treatments, followed by BC + SMS, and the SMS treatment, and 5-9 days later by plants in control conditions. Plants in all treatment groups produced significantly more fruits than controls $(\sim 35 \%$ increase relative to controls). Fruits were formed on $95 \%$ of plants in the SMS treatment, which was not significantly different from plants in the BC + SMS treatment, in which fruits were formed on $80 \%$ of plants. Significantly fewer fruits $(65 \%)$ were formed by plants in the BC treatment group when compared to plants on SMS treatment (Figure 3b).

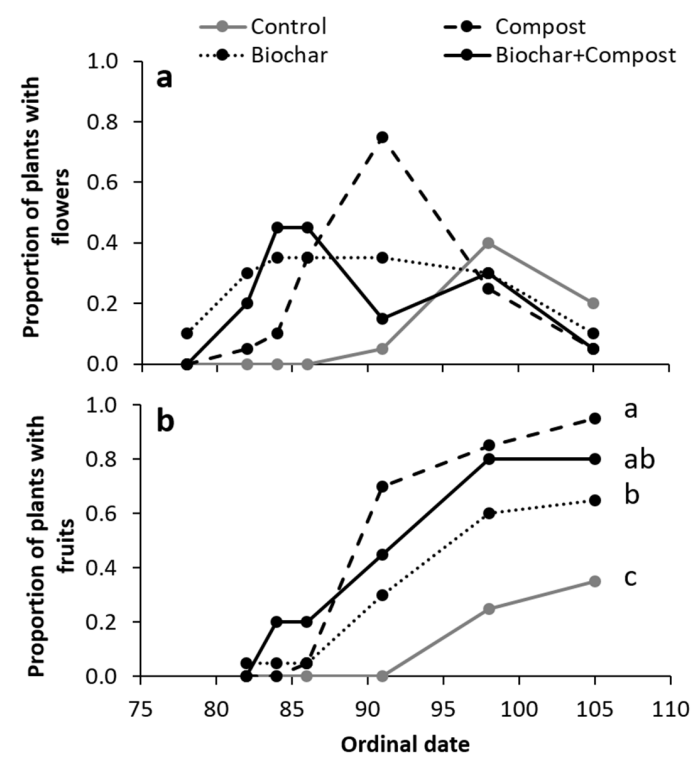

Figure 3. Mean proportion of Abutilon theophrasti plants with (a) flowers and (b) fruits at different soil treatments over time (ordinal date) during the greenhouse experiment.

\subsection{Biomass at Harvest}

Treatments had a significant effect on above- and belowground biomass, and proportion of roots for both $A$. theophrasti and S. purpurea (Table 4b). Tukey's range test showed that BC and SMS significantly increased aboveground biomass $\sim 2.5$-fold, but BC + SMS only $\sim 2$-fold for $A$. theophrasti. All treatments significantly increased belowground biomass of $A$. theophrasti $\sim$-fold when compared to controls. However, there was no significant difference between treatments in root mass fraction for $A$. theophrasti (Figure $4 \mathrm{a}-\mathrm{c}$ ). Reproductive allocation of $A$. theophrasti was significantly influenced by treatments $\left(F_{3,76}=10.33 ; p<0.0001\right)$ and was $\sim 4 \times$ higher in SMS, as well as $2.5 \times$ higher in BC when compared to the control (Table 5). Final plant height of $A$. theophrasti was also significantly influenced by treatments $\left(F_{3,76}=17.41 ; p<0.0001\right)$. Compared to the control, plants were $\sim 60 \%$ taller in SMS and BC treatments, but only 35\% taller in the BC + SMS treatment. Comparisons of means showed that aboveground biomass of $S$. purpurea was significantly decreased by the treatments when compared to controls (reduction of $\sim 33 \%$ ), and that the root mass fraction was significantly higher in the BC and the BC + SMS treatment when compared to controls. However, using Tukey's range 
test, no significant differences between means were found for belowground biomass of S. purpurea (Figure $4 \mathrm{~d}-\mathrm{f}$ ). Mean total branch length of plants at harvest was significantly influenced by treatments $\left(F_{3,55}=6.57 ; p=0.0007\right)$ and was significantly lower in SMS as well as in BC + SMS treatments (by $\sim 30 \%$ ), when compared to controls (Table 5). Stem diameter increase of S. purpurea was not significantly influenced by the treatments $\left(F_{3,55}=2.10 ; p=0.1111\right.$; Table 5$)$.
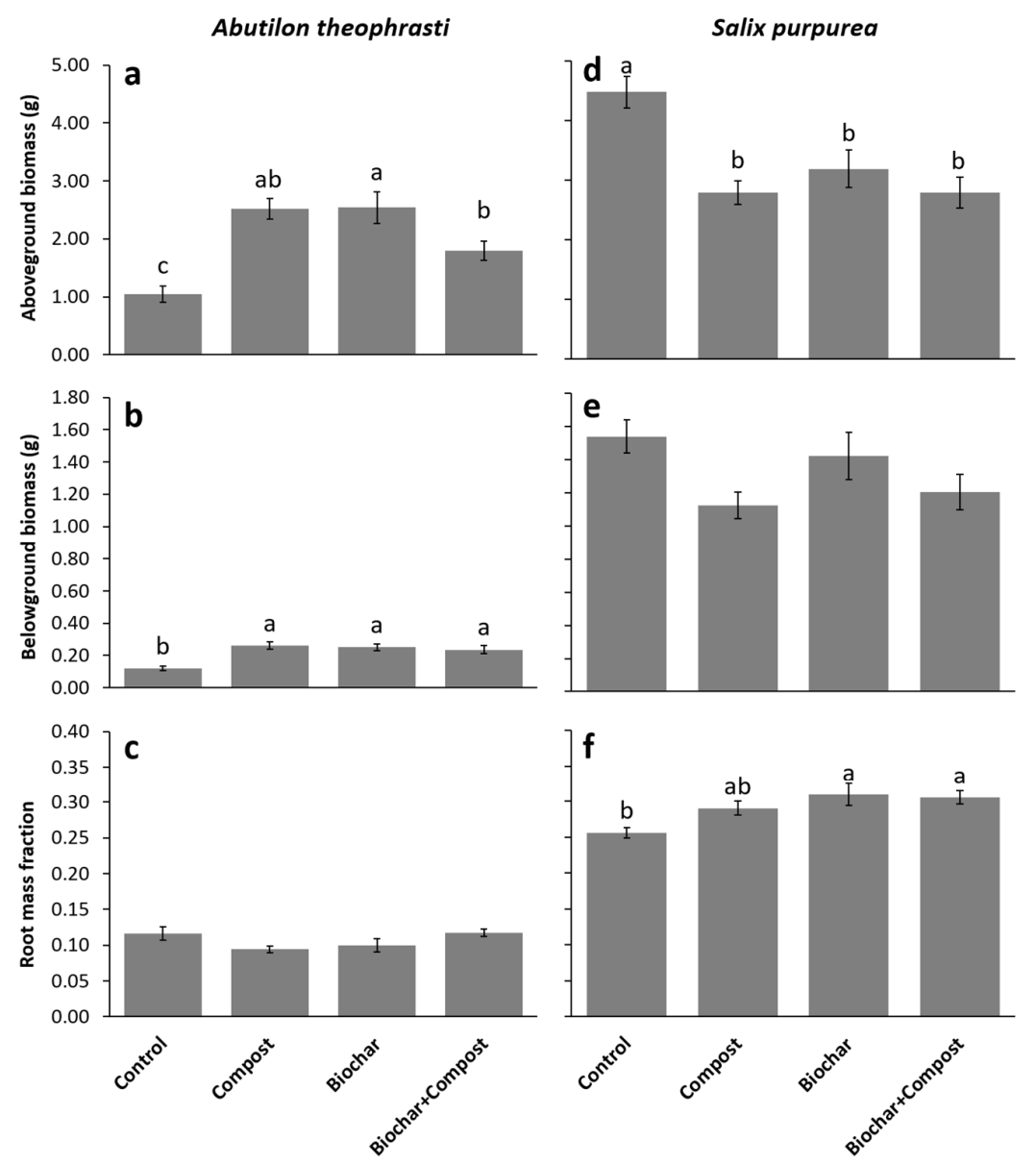

Figure 4. Mean ( \pm standard error) above- and belowground biomass, and root mass fraction at different soil treatments for Abutilon theophrasti $(\mathbf{a}-\mathbf{c})$ and Salix purpurea; $(\mathbf{d}-\mathbf{f})$. Bars in each panel with the same lower case letters do not differ significantly at $p<0.05$ according to Tukey's range test.

\section{Discussion}

We found no evidence to support the general hypothesis that BC and SMS had a positive synergistic effect on plant growth and performance in either plant species. Contrary to this hypothesis, we found that the mixture of $B C$ and SMS generally had neutral or antagonistic interactive effects on plant growth and physiological performance. In $A$. theophrasti, most of the growth and physiological metrics taken in this study displayed antagonistic effects, with maximum leaf area and plant height being most impaired by the mixture of BC and SMS (Table 2). For $A$. theophrasti a weak synergistic effect of BC and SMS was found only in the case of root mass fraction, but this is not a performance metric. For S. purpurea, a synergistic effect of BC and SMS on aboveground biomass was found, but this effect was in the context of negative effects of both soil amendments when applied alone (Table 2). 
Table 5. Measurements (mean \pm standard error) taken at harvest of Abutilon theophrasti and Salix purpurea at different soil treatments. Numbers in each column followed by the same lower case letters do not differ significantly at $p<0.05$ according to Tukey's range test.

\begin{tabular}{ccccc}
\hline \multirow{2}{*}{ Treatment } & \multicolumn{2}{c}{ Abutilon theophrasti } & \multicolumn{2}{c}{ Salix purpurea } \\
\cline { 2 - 5 } & Plant Height $(\mathbf{c m})$ & $\begin{array}{c}\text { Reproductive } \\
\text { Allocation }(\mathrm{g})\end{array}$ & $\begin{array}{c}\text { Total Branch } \\
\text { Length (cm) }\end{array}$ & $\begin{array}{c}\text { Stem Diameter } \\
\text { Gain (Mm) }\end{array}$ \\
\hline Control & $45.8 \pm 3.5 \mathrm{c}$ & $0.06 \pm 0.02 \mathrm{c}$ & $102.6 \pm 6.8 \mathrm{a}$ & $1.40 \pm 0.17 \mathrm{a}$ \\
Compost & $72.7 \pm 3.8 \mathrm{a}$ & $0.23 \pm 0.02 \mathrm{a}$ & $84.2 \pm 9.6 \mathrm{~b}$ & $0.93 \pm 0.15 \mathrm{a}$ \\
Biochar & $74.3 \pm 2.4 \mathrm{ab}$ & $0.15 \pm 0.03 \mathrm{~b}$ & $69.3 \pm 5.5 \mathrm{ab}$ & $1.32 \pm 0.16 \mathrm{a}$ \\
Biochar + Compost & $62.0 \pm 2.6 \mathrm{~b}$ & $0.16 \pm 0.02 \mathrm{bc}$ & $63.3 \pm 6.0 \mathrm{~b}$ & $1.34 \pm 0.15 \mathrm{a}$ \\
\hline
\end{tabular}

Full factorial designs are necessary to test for interaction terms and thus infer synergistic or antagonistic effects. Despite the claim of "synergistic effects" of BC and compost on plant performance (and soil function) [30], we are aware of only a few prior studies that used a true full factorial design involving $\mathrm{BC}+$ compost mixtures [43,45,49], and analyses presented did not explicitly test for synergism. Other studies examining BC and compost as soil amendments have not presented strong evidence for synergistic effects based on a conventional definition or analysis. The majority of published studies have used a "substitutive" design for BC plus compost treatments, where the total dosage of soil amendment is kept constant, but the ratios changed (e.g., [37,39,41,46-48]; others have used experimental designs that do not involve additive combinations [38,42,46], or that do not include a BC-only treatment [31]. In the "substitutive" cases, the BC + compost treatments are modified in terms of both the $\mathrm{BC}$ dosage and addition of compost, and one thus cannot infer the independent effects of either change (analogous to the case of "substitutive" designs in plant competition studies [61]).

Why would BC + compost mixtures produce antagonistic effects on plant performance? As an organic fertilizer, compost (including SMS) provides plants with important nutrients and facilitates subsequent uptake. Similarly, unweathered BC also provides a short-term pulse of certain important nutrients, in particular K and P [18,62]. If growth responses to BC and SMS treatments are mainly due to nutrient provision, then a saturation of plant nutrient demands will often result in a non-additive positive effect on plant growth (e.g., [63]), and may lead to a decline in plant growth at high levels [28] (p. 46). Alternatively, the combination of BC and SMS may have resulted in an oversupply of toxic elements (e.g., Al, Pb, Mn, As), or nutrients required at only very low levels (e.g., Mn, B) [3,23,25,64,65]. For example, high amounts of $\mathrm{Mn}$ are present in the $\mathrm{BC}$ used in our experiment (Table 1); while $\mathrm{Mn}$ is important for plant growth as a micronutrient [66], it can be toxic to plants at amounts that are highly variable between plant species [67] and environmental conditions [68-70].

In addition, biochar has a high sorption ability [16] that can lead to a reduced availability of nutrients, in particular mineralized $\mathrm{N}$ or available $\mathrm{P}$, for plants under certain circumstances $[48,71,72]$. Thus, when compared to the SMS treatment, the availability of nutrients to the plants in the BC + SMS treatment might have been reduced, leading to the observed reduction in plant growth and physiological performance. Indeed, Kammann et al. [49] report antagonism in Chenopodium quinoa when $\mathrm{BC}$ was combined with manure compost in a sandy-loam soil supplemented with nitrogen fertilizer, concomitant with strong nitrate sorption.

One potential way forward in offsetting antagonistic effects $B C+$ compost applications is to co-compost prior to application. Several studies have demonstrated increased supply of nutrients $\left(\mathrm{K}, \mathrm{P}, \mathrm{Ca}, \mathrm{NH}_{4}, \mathrm{NO}_{3}\right.$ ) when manure-based composts were co-composted with wood BCs to maturity prior to application, ultimately increasing crop yield and biomass [43,44,49]. In Kammann et al. [49], co-composting produced a synergistic effect, rather than the antagonistic effect observed in the $\mathrm{BC}+$ compost treatment, due to enriched nitrate and phosphate. In the present study, co-composting prior to application may have alleviated antagonistic effects. Much additional work needs to be conducted to explore the mechanisms responsible for synergism in co-composted $\mathrm{BC}$ mixtures.

Positive effects of BC and SMS on plant growth have been found for both annual and perennial plants $[12,13,20,21]$. Fast-growing annual plants generally show higher nutritional demands than 
woody perennials [73]. Prior studies have specifically found very high responses of $A$. theophrasti to nutrient additions [50]. This species did show more pronounced responses to the soil amendments than S. purpurea. In particular, $A$. theophrasti showed a $\sim 3$-fold increase in photosynthetic rate in response to all three soil amendment treatments, while S. purpurea showed no significant response (Figure 2). Since S. purpurea was potted as cuttings, it is possible that nutrients in initial cuttings were translocated to offset nutrient deprivation. Our data are consistent with patterns of high interspecific variation in responses to biochar (e.g., $[13,19])$, and suggest that certain early-successional species are particularly responsive (see [74]).

Biochar effects on plant reproduction have received relatively little attention in the literature (e.g., [15,75]). The reproductive performance of $A$. theophrasti was strongly influenced by the soil treatments. All soil amendment treatments induced earlier flowering and fruit production when compared to plants in control treatments. Interestingly, the first flowers and first fruits were formed by plants in $\mathrm{BC}$ treatments (BC alone or in combination with SMS). BC can release volatile compounds such as ethylene into the soil $[76,77]$. Ethylene is known to be a gaseous plant hormone, which is responsible for inducing the formation of flowers in certain plants (e.g., [78-81]), and may therefore explain the earlier flowering of plants with BC treatments. However, most flowers and fruits were eventually produced by plants in compost treatments, which is also reflected in the higher reproductive allocation of plants receiving this treatment.

In the present study, we used a mixed-wood BC at $1.5 \mathrm{~kg} \cdot \mathrm{m}^{-2}$ and a mushroom compost at $\sim 1.8 \mathrm{~kg} \cdot \mathrm{m}^{-2}$. These dosages are not excessively high, and are broadly consistent with studies that found significant effects of compost [26] and BC [54] on growth of plants in temperate environments. However, the effect of both $\mathrm{BC}$ and compost on the performance of plants is highly variable and depends on feedstock, dosage, and soil type, and the fertility of the plant it is applied to $[11,82,83]$. The SMS compost used here is slightly more acidic when compared to manure-based composts used in other similar studies $[43,44,49]$. The BC used here was produced at moderately high pyrolysis temperatures and has high surface area and porosity, characteristics that enable its use as a sorptive agent of soil pollutants in other studies [53,54]. Highly-sorptive BCs from high pyrolysis temperatures are desirable in restoration contexts where soil pollutants limit plant growth. Comparative studies testing a variety of $\mathrm{BC}$ and compost types across a spectrum of plant growth forms and soil types are necessary to untangle the mechanisms responsible for interactive effects of $\mathrm{BC}+$ compost.

\section{Conclusions}

The generalization that $\mathrm{BC}$ and compost mixtures have synergistic effects on plant growth and performance is not supported by this study. On the contrary, we have shown that even antagonistic effects of BC and compost mixtures can occur. Full factorial design experiments followed by an appropriate statistical analysis including the interaction term of the factors are needed to accurately test for synergism. More broadly, investigating the underlying mechanisms of synergistic or antagonistic effects of $\mathrm{BC}$ and other fertilizers and soil conditioners on plant growth is important in realizing the potential of biochar as a tool in ecosystem management.

Acknowledgments: We thank all students in the 2015 Stresses in the Forest Environment class (Faculty of Forestry, University of Toronto), and also W. Merrit, L. Sujeeun, S. Dehdashti, and A. Mansour for taking measurements on plants in the greenhouse and laboratory. Naresh Thevasthasan at the University of Guelph is thanked for assistance in obtaining Salix purpurea cuttings, and Julian Cleary and Adam Martin at the University of Toronto for reviewing an earlier version of this paper. This project was supported in part by grants from the Canadian Natural Science and Engineering Research Council to S.M.S. and S.C.T.

Author Contributions: M.L.S., N.V.G., and S.C.T. designed the experiment. M.L.S., N.V.G., S.D., V.H., N.L., J.M., E.T., and C.W. maintained the experiment and collected the data, and M.L.S., N.V.G., and S.C.T. analyzed the data. M.L.S., N.V.G., S.D., V.H., N.L., J.M., E.T., C.W., S.M.S., and S.C.T. wrote the paper.

Conflicts of Interest: The authors declare no conflict of interest. 


\section{References}

1. Park, J.H.; Choppala, G.K.; Bolan, N.S.; Chung, J.W.; Chuasavathi, T. Biochar reduces the bioavailability and phytotoxicity of heavy metals. Plant Soil 2011, 348, 439-451. [CrossRef]

2. Lashari, M.S.; Liu, Y.; Li, L.; Pan, W.; Fu, J.; Pan, G.; Zheng, J.; Zheng, J.; Zhang, X.; Yu, X. Effects of amendment of biochar-manure compost in conjunction with pyroligneous solution on soil quality and wheat yield of a salt-stressed cropland from Central China Great Plain. Field Crops Res. 2013, 144, 113-118. [CrossRef]

3. Kloss, S.; Zehetner, F.; Dellantonio, A.; Hamid, R.; Ottner, F.; Liedtke, V.; Schwanninger, M.; Gerzabek, M.H.; Soja, G. Characterization of slow pyrolysis biochars: Effects of feedstocks and pyrolysis temperature on biochar properties. J. Environ. Qual. 2012, 41, 990-1000. [CrossRef] [PubMed]

4. Wardle, D.A.; Zackrisson, O.; Nilsson, M.C. The charcoal effect in Boreal forests: Mechanisms and ecological consequences. Oecologia 1998, 115, 419-426. [CrossRef]

5. DeLuca, T.H.; MacKenzie, M.D.; Gundale, M.J.; Holben, W.E. Wildfire-Produced charcoal directly influences nitrogen cycling in ponderosa pine forests. Soil Sci. Soc. Am. J. 2012, 70, 448-453. [CrossRef]

6. Bruun, E.W.; Petersen, C.T.; Hansen, E.; Holm, J.K.; Hauggaard-Nielsen, H. Biochar amendment to coarse sandy subsoil improves root growth and increases water retention. Soil Use Manag. 2014, 30, $109-118$. [CrossRef]

7. Lehmann, J.; Joseph, S. Biochar for environmental management: An introduction. In Biochar for Environmental Management: Science and Technology; Lehmann, J., Joseph, S., Eds.; Earthscan: London, UK, 2009; pp. 1-12.

8. Lehmann, J. Bio-Energy in the black. Front. Ecol. Environ. 2007, 5, 381-387. [CrossRef]

9. Sohi, S.; Krull, E.; Lopez-Capel, E.; Bol, R. A review of biochar and its use and function in soil. Adv. Agron. 2010, 105, 47-82.

10. Woolf, D.; Amonette, J.E.; Street-Perrott, F.A.; Lehmann, J.; Joseph, S. Sustainable biochar to mitigate global climate change. Nat. Commun. 2010, 1, 1-9. [CrossRef] [PubMed]

11. Jeffery, S.; Verheijen, F.G.A.; van der Velde, M.; Bastos, A.C. A quantitative review of the effects of biochar application to soils on crop productivity using meta-analysis. Agric. Ecosyst. Environ. 2011, 144, $175-187$. [CrossRef]

12. Biederman, L.A.; Harpole, W.S. Biochar and its effects on plant productivity and nutrient cycling: A meta-analysis. GCB Bioenergy 2013, 5, 202-214. [CrossRef]

13. Thomas, S.C.; Gale, N. Biochar and forest restoration: A review and meta-analysis of tree growth responses. New For. 2015, 46, 931-946. [CrossRef]

14. Zhao, L.; Cao, X.; Mašek, O.; Zimmerman, A. Heterogeneity of biochar properties as a function of feedstock sources and production temperatures. J. Hazard. Mater. 2013, 256, 1-9. [CrossRef] [PubMed]

15. Thomas, S.C.; Frye, S.; Gale, N.; Garmon, M.; Launchbury, R.; Machado, N.; Melamed, S.; Murray, J.; Petroff, A.; Winsborough, C. Biochar mitigates negative effects of salt additions on two herbaceous plant species. J. Environ. Manag. 2013, 129, 62-68. [CrossRef] [PubMed]

16. Atkinson, C.J.; Fitzgerald, J.D.; Hipps, N.A. Potential mechanisms for achieving agricultural benefits from biochar application to temperate soils: A review. Plant Soil 2010, 337, 1-18. [CrossRef]

17. Major, J.; Rondon, M.; Molina, D.; Riha, S.J.; Lehmann, J. Maize yield and nutrition during 4 years after biochar application to a Colombian savanna oxisol. Plant Soil 2010, 333, 117-128. [CrossRef]

18. Sackett, T.E.; Basiliko, N.; Noyce, G.L.; Winsborough, C.; Schurman, J.; Ikeda, C.; Thomas, S.C. Soil and greenhouse gas responses to biochar additions in a temperate hardwood forest. GCB Bioenergy 2015, 7, 1062-1074. [CrossRef]

19. Pluchon, N.; Gundale, M.J.; Nilsson, M.C.; Kardol, P.; Wardle, D.A. Stimulation of boreal tree seedling growth by wood-derived charcoal: Effects of charcoal properties, seedling species and soil fertility. Funct. Ecol. 2014, 28, 766-775. [CrossRef]

20. Sainz, M.J.; Taboada-Castro, M.T.; Vilarino, A. Growth, mineral nutrition and mycorrhizal colonization of red clover and cucumber plants grown in a soil amended with composted urban wastes. Plant Soil 1998, 205, 85-92. [CrossRef]

21. Soumare, M. Effects of a municipal solid waste compost and mineral fertilization on plant growth in two tropical agricultural soils of Mali. Bioresour. Technol. 2003, 86, 15-20. [CrossRef] 
22. Maynard, A.A. Sustained vegetable production for three years using composted animal manures. Compost Sci. Util. 2013, 2, 88-96. [CrossRef]

23. Stewart, D.P.C.; Cameron, K.C.; Cornforth, I.S.; Main, B.E. Release of sulphate, potassium, calcium and magnesium from spent mushroom compost under laboratory conditions. Biol. Fert. Soils 1997, 26, 146-151. [CrossRef]

24. Stewart, D.P.C.; Cameron, K.C.; Cornforth, I.S. Effects of spent mushroom substrate on soil chemical conditions and plant growth in an intensive horticultural system: A comparison with inorganic fertiliser. Aust. J. Soil Res. 1998, 36, 185-199. [CrossRef]

25. Stamatiadis, S.; Werner, M.; Buchanan, M. Field assessment of soil quality as affected by compost and fertilizer application in a broccoli field (San Benito County, California). Appl. Soil Ecol. 1999, 12, 217-225. [CrossRef]

26. Polat, E.; Uzun, H.I.; Topçuoglu, B.; Önal, K.; Onus, A.N.; Karaca, M. Effects of spent mushroom compost on quality and productivity of cucumber (Cucumis sativus L.) grown in greenhouses. Afr. J. Biotechnol. 2009, 8, 176-180.

27. Chong, C.; Rinker, D.L. Use of spent mushroom substrate for growing containerized woody ornamentals: An overview. Compost Sci. Util. 1994, 2, 45-53. [CrossRef]

28. Tisdale, S.L.; Nelson, W.L.; Beaton, J.D. Soil Fertility and Fertilizers; Collier Macmillan Publishers: London, UK, 1985.

29. Steiner, C.; Das, K.C.; Melear, N.; Lakly, D. Reducing nitrogen loss during poultry litter composting using biochar. J. Environ. Qual. 2010, 39, 1236-1242. [CrossRef] [PubMed]

30. Fischer, D.; Glaser, B. Synergisms between compost and biochar for sustainable soil amelioration. In Management of Organic Waste; Kumar, S., Ed.; InTech: Rijeka, Croatia, 2012; pp. 167-198.

31. Liu, J.; Schulz, H.; Brandl, S.; Miehtke, H.; Huwe, B.; Glaser, B. Short-Term effect of biochar and compost on soil fertility and water status of a Dystric Cambisol in NE Germany under field conditions. J. Plant Nutr. Soil Sci. 2012, 175, 698-707. [CrossRef]

32. Pietikäinen, J.; Kiikkilä, O.; Fritze, H. Charcoal as a habitat for microbes and its effect on the microbial community of the underlying humus. Oikos 2003, 89, 231-242. [CrossRef]

33. Tuomela, M.; Vikman, M.; Hatakka, A.; Itävaara, M. Biodegradation of lignin in a compost environment: A review. Bioresour. Technol. 2000, 72, 169-183. [CrossRef]

34. Cheng, C.-H.; Lehmann, J. Ageing of black carbon along a temperature gradient. Chemosphere 2009, 75, 1021-1027. [CrossRef] [PubMed]

35. Zimmerman, A.R. Abiotic and microbial oxidation of laboratory-produced black carbon (biochar). Environ. Sci. Technol. 2010, 44, 1295-1337. [CrossRef] [PubMed]

36. Prost, K.; Borchard, N.; Siemens, J.; Kautz, T.; Séquaris, J. Biochar affected by composting with farmyard manure. J. Environ. Qual. 2012, 42, 164-172. [CrossRef] [PubMed]

37. Beesley, L.; Inneh, O.S.; Norton, G.J.; Moreno-Jimenez, E.; Pardo, T.; Clemente, R.; Dawson, J.J. Assessing the influence of compost and biochar amendments on the mobility and toxicity of metals and arsenic in a naturally contaminated mine soil. Environ. Pollut. 2014, 186, 195-202. [CrossRef] [PubMed]

38. Major, J.; Steiner, C.; Ditommaso, A.; Falcão, N.P.; Lehmann, J. Weed composition and cover after three years of soil fertility management in the central Brazilian Amazon: Compost, fertilizer, manure and charcoal applications. Weed Biol. Manag. 2005, 5, 69-76. [CrossRef]

39. Steiner, C.; Glaser, B.; Geraldes-Teixeira, W.; Lehmann, J.; Blum, W.E.; Zech, W. Nitrogen retention and plant uptake on a highly weathered central Amazonian Ferralsol amended with compost and charcoal. J. Plant Nutr. Soil Sci. 2008, 171, 893-899. [CrossRef]

40. Beesley, L.; Moreno-Jimenez, E.; Gomez-Eyles, J.L. Effects of biochar and greenwaste compost amendments on mobility, bioavailability, and toxicity of inorganic and organic contaminants in a multi-element polluted soil. Environ. Pollut. 2010, 158, 2282-2287. [CrossRef] [PubMed]

41. Suddick, E.C.; Six, J. An estimation of annual nitrous oxide emissions and soil quality following the amendment of high temperature walnut shell biochar and compost to a small scale vegetable crop rotation. Sci. Total Environ. 2013, 465, 298-307. [CrossRef] [PubMed]

42. Schmidt, H.P.; Kammann, C.; Niggli, C.; Evangelou, M.W.; Mackie, K.A.; Abiven, S. Biochar and biochar-compost as soil amendments to a vineyard soil: Influences on plant growth, nutrient uptake, plant health and grape quality. Agric. Ecosyst. Environ. 2014, 191, 117-123. [CrossRef] 
43. Agegnehu, G.; Bass, A.M.; Nelson, P.N.; Bird, M.I. Benefits of biochar, compost and biochar-compost for soil quality, maize yield and greenhouse gas emissions in a tropical agricultural soil. Sci. Total Environ. 2016, 543, 295-306. [CrossRef] [PubMed]

44. Bass, A.M.; Bird, M.I.; Kay, G.; Muirhead, B. Soil properties, greenhouse gas emissions and crop yield under compost, biochar and co-composted biochar in two tropical agronomic systems. Sci. Total Environ. 2016, 550, 459-470. [CrossRef] [PubMed]

45. Karami, N.; Clemente, R.; Moreno-Jiménez, E.; Lepp, N.W.; Beesley, L. Efficiency of green waste compost and biochar soil amendments for reducing lead and copper mobility and uptake to ryegrass. J. Hazard. Mater. 2011, 191, 41-48. [CrossRef] [PubMed]

46. Schulz, H.; Glaser, B. Effects of biochar compared to organic and inorganic fertilizers on soil quality and plant growth in a greenhouse experiment. J. Plant Nutr. Soil Sci. 2012, 175, 410-422. [CrossRef]

47. Schulz, H.; Dunst, G.; Glaser, B. Positive effects of composted biochar on plant growth and soil fertility. Agron. Sustain. Dev. 2012, 33, 817-827. [CrossRef]

48. Vandecasteele, B.; Sinicco, T.; D’Hose, T.; Nest, T.V.; Mondini, C. Biochar amendment before or after composting affects compost quality and $\mathrm{N}$ losses, but not $\mathrm{P}$ plant uptake. J. Environ. Manag. 2016, 168, 200-209. [CrossRef] [PubMed]

49. Kammann, C.I.; Schmidt, H.P.; Messerschmidt, N.; Linsel, S.; Steffens, D.; Müller, C.; Koyro, H.W.; Conte, P.; Stephen, J. Plant growth improvement mediated by nitrate capture in co-composted biochar. Sci. Rep. 2015, 5. [CrossRef]

50. Benner, B.L.; Bazzaz, F.A. Response of the annual Abutilon theophrasti Medic. (Malvaceae) to timing of nutrient availability. Am. J. Bot. 1985, 72, 320-323. [CrossRef]

51. Volk, T.A.; Abrahamson, L.P.; Nowak, C.A.; Smart, L.B.; Tharakan, P.J.; White, E.H. The development of short-rotation willow in the northeastern United States for bioenergy and bioproducts, agroforestry and phytoremediation. Biomass Bioenergy 2006, 30, 715-727. [CrossRef]

52. Denyes, M.J.; Matovic, D.; Zeeb, B.A.; Rutter, A. Report on the production and characterization of biochar produced at Burt's Greenhouse. 2006. Available online: http://burtsgh.com/wpr/wp-content/uploads/ 2013/12/Report_on_the_Production_and_Characterization_Biochar_Produced_at_BurtsGreenhouses_ Final_O1.pdf (accessed on 24 January 2017).

53. Denyes, M.J.; Langlois, V.S.; Rutter, A.; Zeeb, B.A. The use of biochar to reduce soil PCB bioavailability to Cucurbita pepo and Eisenia fetida. Sci. Total Environ. 2012, 437, 76-82. [CrossRef] [PubMed]

54. Denyes, M.J.; Rutter, A.; Zeeb, B.A. In situ application of activated carbon and biochar to PCB-contaminated soil and the effects of mixing regime. Environ. Pollut. 2013, 182, 201-208. [CrossRef] [PubMed]

55. Gale, N.V.; Sackett, T.; Thomas, S.C. Thermal treatment and leaching of biochar alleviates plant growth inhibition from mobile organic compounds. PeerJ 2016, 4, e2385. [CrossRef] [PubMed]

56. Rajkovich, S.; Enders, A.; Hanley, K.; Hyland, C.; Zimmerman, A.R.; Lehmann, J. Corn growth and nitrogen nutrition after additions of biochars with varying properties to a temperate soil. Biol. Fert. Soils 2002, 48, 271-284. [CrossRef]

57. Thomas, S.C.; Jasienski, M.; Bazzaz, F.A. Early vs. asymptotic growth responses of herbaceous plants to elevated $\mathrm{CO}_{2}$. Ecology 1999, 80, 1552-1567. [CrossRef]

58. Maxwell, K.; Johnson, G.N. Chlorophyll fluorescence-A practical guide. J. Exp. Bot. 2000, 51, 659-668. [CrossRef] [PubMed]

59. R Core Team. R: A Language and Environment for Statistical Computing; R Foundation for Statistical Computing: Vienna, Austria, 2014.

60. SAS Institute Inc. SAS Studio 3.4: User's Guide; SAS Institute Inc.: Cary, NC, USA, 2015.

61. Firbank, L.G.; Watkinson, A.R. On the analysis of competition within two-species mixtures of plants. J. Appl. Ecol. 1985, 22, 503-517. [CrossRef]

62. Novak, J.M.; Busscher, W.J.; Laird, D.L.; Ahmedna, M.; Watts, D.W.; Niandou, M.A. Impact of biochar amendment on fertility of a southeastern coastal plain soil. Soil Sci. 2009, 174, 105-112. [CrossRef]

63. Tessier, J.T.; Raynal, D.J. Use of nitrogen to phosphorus ratios in plant tissue as an indicator of nutrient limitation and nitrogen saturation. J. Appl. Ecol. 2003, 40, 523-534. [CrossRef]

64. Kloss, S.; Zehetner, F.; Oburger, E.; Buecker, J.; Kitzler, B.; Wenzel, W.W.; Wimmer, B.; Soja, G. Trace element concentrations in leachates and mustard plant tissue (Sinapis alba L.) after biochar application to temperate soils. Sci. Total Environ. 2014, 481, 498-508. [CrossRef] [PubMed] 
65. Domene, X.; Hanley, K.; Enders, A.; Lehmann, J. Short-Term mesofauna responses to soil additions of corn stover biochar and the role of microbial biomass. Appl. Soil Ecol. 2015, 89, 10-17. [CrossRef]

66. Hänsch, R.; Mendel, R.R. Physiological functions of mineral micronutrients ( $\mathrm{Cu}, \mathrm{Zn}, \mathrm{Mn}, \mathrm{Fe}, \mathrm{Ni}, \mathrm{Mo}, \mathrm{B}, \mathrm{Cl})$. Curr. Opin. Plant Biol. 2009, 12, 259-266. [CrossRef] [PubMed]

67. Edwards, D.G.; Asher, C.J. Tolerance of crop and pasture species to manganese toxicity. In Proceedings of the Ninth Plant Nutrition Colloquium; Scaife, A., Ed.; Commonwealth Agricultural Bureaux: Warwick, England, 1982; pp. 145-150.

68. Horst, W.J. The physiology of manganese toxicity. In Manganese in Soils and Plants; Graham, R.D., Hannam, R.J., Uren, N.C., Eds.; Kluwer Academic Publishers: Dordrecht, The Netherland, 1988; pp. 175-188.

69. Le Bot, J.; Goss, M.J.; Carvalho, G.P.R.; van Beusichem, M.L.; Kirby, E.A. The significance of the magnesium to manganese ratio in plant tissues for growth and alleviation of manganese toxicity in tomato (Lycopersicon esculentum) and wheat (Triticum sativum) plants. Plant Soil 1990, 124, 205-210. [CrossRef]

70. Wang, J.; Evangelou, B.P.; Nielsen, M.T. Surface chemical properties of purified root cell walls from two tobacco genotypes exhibiting different tolerance to manganese toxicity. Plant Physiol. 1992, 100, 496-501. [CrossRef] [PubMed]

71. DeLuca, T.H.; Gundale, M.J.; MacKenzie, M.D.; Jones, D.L. Biochar effects on soil nutrient transformations. In Biochar for Environmental Management: Science, Technology and Implementation; Lehmanm, J., Joseph, S., Eds.; Taylor and Francis: New York, NY, USA, 2015; pp. 421-454.

72. Vandecasteele, B.; Reubens, B.; Willekens, K.; de Neve, S. Composting for increasing the fertilizer value of chicken manure: Effects of feedstock on P availability. Waste Biomass Valoriz. 2015, 5, 491-503. [CrossRef]

73. Chapin, F.S. The mineral nutrition of wild plants. Annu. Rev. Ecol. Syst. 1980, 11, 233-260. [CrossRef]

74. Gale, N.V.; Halim, M.A.; Horsburgh, M.; Thomas, S.C. Comparative responses of early-successional plants to charcoal soil amendments. University of Toronto: Toronto, Canada, Unpublished work. 2017.

75. Conversa, G.; Bonasia, A.; Lazzizera, C.; Elia, A. Influence of biochar, mycorrhizal inoculation, and fertilizer rate on growth and flowering of Pelargonium (Pelargonium zonale L.) plants. Front. Plant Sci. 2015, 6, 429. [CrossRef] [PubMed]

76. Spokas, K.A.; Baker, J.M.; Reicosky, D.C. Ethylene: Potential key for biochar amendment impacts. Plant Soil 2010, 333, 443-452. [CrossRef]

77. Fulton, W.; Gray, M.; Prahl, F.; Kleber, M. A simple technique to eliminate ethylene emissions from biochar amendment in agriculture. Agron. Sustain. Dev. 2013, 33, 469-474. [CrossRef]

78. Burg, S.P.; Burg, E.A. Auxin-induced ethylene formation: Its relation to flowering in the pineapple. Science 1966, 152, 1269. [CrossRef] [PubMed]

79. Ogawara, T.; Higashi, K.; Kamada, H.; Ezura, H. Ethylene advances the transition from vegetative growth to flowering in Arabidopsis thaliana. J. Plant Physiol. 2013, 160, 1335-1340. [CrossRef] [PubMed]

80. Dukovski, D.; Bernatzky, R.; Han, S. Flowering induction of Guzmania by ethylene. Sci. Hortic. 2006, 110, 104-108. [CrossRef]

81. Abeles, F.B.; Morgan, P.W.; Saltveit, M.E., Jr. Ethylene in Plant Biology, 2nd ed.; Academic Press: San Diego, CA, USA, 2012.

82. Wróblewska, H. Studies on the effect of compost made of post-use wood waste on the growth of willow plants. Mol. Cryst. Liq. Crys. 2008, 483, 352-366. [CrossRef]

83. Spokas, K.A.; Cantrell, K.B.; Novak, J.M.; Archer, D.W.; Ippolito, J.A.; Collins, H.P.; Boateng, A.A.; Lima, I.M.; Lamb, M.C.; McAloon, A.J.; et al. Biochar: A synthesis of its agronomic impact beyond carbon sequestration. J. Environ. Qual. 2012, 41, 973-989. [CrossRef] [PubMed]

(C) 2017 by the authors; licensee MDPI, Basel, Switzerland. This article is an open access article distributed under the terms and conditions of the Creative Commons Attribution (CC BY) license (http:/ / creativecommons.org/licenses/by/4.0/). 